\title{
A Case of Self-healing of a Broken Forearm in Myotis brandtii (Eversmann, 1845)
} PRZYPADEK SAMOWYLECZENIA ZEAMANIA PRZEDRAMIENIA U MYOTIS BRANDTII
(EVERSMANN, 1845)

- Wiesław BOGDANOWICZ \& Zbigniew URBAŃCZYK

Bogdanowicz W. \& Urbańczyk Z., 1986: A case of self-healing of a broken forearm in Myotis brandtii (Eversmann, 1845). Acta theriol, 31, 14: $180-181$ [With 1 Fig.]

A case of self-healing of a broken forearm in one Myotis brandtii specimen is described. The animal was found in the "Nietoperek" bat reserve, Western Poland.

[Mammals Res. Inst. PAS, 17-230 Białowieża, Poland (WB) and Osiedle Jana III Sobieskiego 26D/142, 60-683 Poznań, Poland (ZU)].

Fractures of the wing bones in bats are serious injuries which, since they greatly reduce the animal's flying ability, frequently prove fatal. Cases are, however, known in which injuries of this kind have successfully healed, both in the phalanges of digits and the bones of the metacarpus (Stebbings, 1966; Davis, 1968; Davis \& Doster, 1972). A description is given below of the only case known to the authors of self-healing of a fractured forearm.

On October 22nd, 1982 a male Brandt's bat with a healed fracture of the right forearm was found in the underground passages of the "Nietoperek" bat reserve (Western Poland) (see Bagrowska-Urbańczyk \& Urbańczyk, 1983). The forearm of this bat had been injured in the middle part of the radius, while the ulna would appear to have been left intact (Fig. 1). There was a distinct callus in the place where the

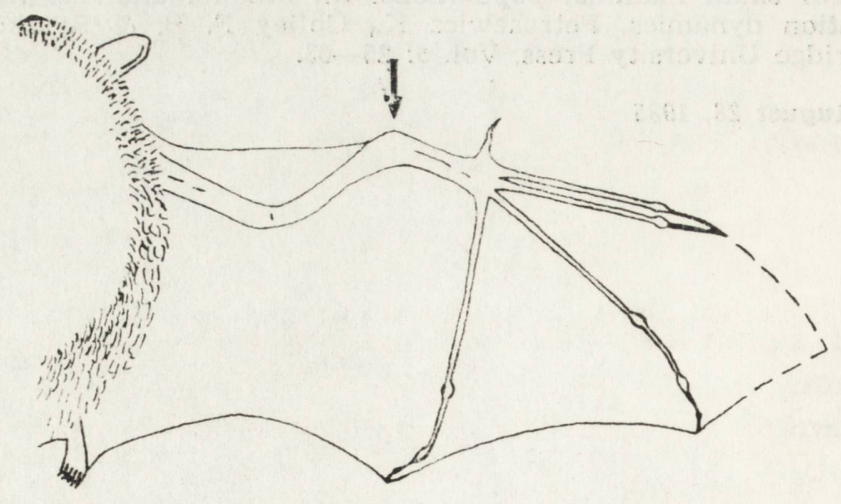

Fig. 1. Natural healing of a broken forearm in a Brandt's bat. The drawing was made directly from a slide, now kept in the Mammals Research Institute and registered under no. 1954. 
bone had coalesced, formed as the results of intensified bone tissue deposit between the separated parts of the diaphysis. This form of regeneration was defined by Liosner (1975) as „,regeneration by means of supplementing defects" (see also Halstead, 1974). During the period from 1975-1984 two further cases of such serious injury to the bone system were observed in the "Nietoperek" bat reserve during all the winter inspections of about 5,000 bats - the animals concerned were Myotis nattereri (Kuhl, 1818) and M. daubentoni (Kuhl, 1819), but they had caused the bats' death.

The general appearance of the animal, in particular the fresh scar on the dorsal side of the body at the level of the fracture, indicated that the injury had been sustained a relatively short time before the bat was found. It is very likely that the injury occurred at the start of hibernation, which under Polish conditions begins at the earliest at the beginning of September in representatives of this species. The self-healing of the broken forearm must therefore have taken place within 50-52 days, or even earlier. Northway (1975) reported that a broken forearm can become completely heald aefter 31 days of an intense therapy. These data agree to a considerable extent with the results obtained by Davis (1968) and Davis \& Doster (1972), who found complete concretion of the broken phalanges of the digits within a maximum of 54 days in individuals of Antrozous pallidus (Le Conte, 1856).

\section{REFERENCES}

Bagrowska-Urbańczyk E. \& Urbańczyk Z., 1983: Structure and dynamics of a winter colony of bats. Acta theriol., 28: 183-196. - Davis R., 1968: Wing defects in a population of pallid bats. Am. Midl. Nat., 79: 388-395. - Davis R. \& Doster S. E., 1972: Wing repair in pallid bats. J. Mamm., 53: 377-378. - Halstead L. B., 1974: Vertebrate hard tissues. Wykeham Sci. Ser., 30: I-X+1-179. - Liosner L. D., 1975: K charakteristike regeneracionnoj sposobnosti mlekopitajuščich. Ontogenez, 6: 450-457. - Northway R. B., 1975: Repair of fractured radius and ulna: in a brown bat. Vet. Med.. Small Anim. Clin., 70: 952. - Stebbings R. 'E., 1966: A population study of bats of the genus Plecotus. J. Zool., 150: 53-75.

Accepted, April 4, 1985. 